\title{
Witchcraft Accusations and Hybrid Formulations in Papua New Guinea
}

\author{
Philip Gibbs
}

The paper "Christian Pastors and (Alleged) Child Witches in Kinshasa, DRC,” by Robert J. Priest, Abel Ngolo, and Timothy Stabell (2020), tells of a new phenomenon in the Democratic Republic of Congo where children are being accused of being dangerous witches. The paper highlights the trusted role of Christian church leaders, including pastors, prophets, apostles, and intercessors in addressing these witchcraft suspicions and accusations. The focus is on findings from a survey of the experiences, understandings, and practices of church leaders in Kinshasa and of various activities of the churches. African churches have been central both in propagating child-witch ideologies, and in working to resist child-witch ideologies, accusations and deliverance practices.

This paper is a response from Papua New Guinea (PNG), on the other side of the world in Oceania, where witchcraft accusations are also a major concern. The vast majority of Papua New Guineans profess to be Christian and Christian church leaders play a significant role in dealing with the phenomenon that has been termed "Sorcery Accusation Related Violence". ${ }^{2}$ This response will comment on the DRC report, with reference to epistemological and linguistic shifts and emerging hybrid formulations contributing to contemporary efforts to address the issue of witchcraft accusations from the PNG experience, particularly the experience from the Enga Province in the PNG Highlands. $^{3}$

In PNG, as part of the Sorcery National Action Plan (SARV NAP), research is being carried out in three of the twenty one provinces in the country to ascertain who is being accused of sorcery or witchcraft (the terms sorcery and witchcraft, though theoretically different, tend to be used arbitrarily in PNG). ${ }^{4}$ The research investigates where, why, how often, by whom and how sorcery/witchcraft accusations are changing over time. It also investigates what accusations lead to violence at times and not at other times and what regulatory systems exist to overcome sorcery/witchcraft accusation related violence. After almost three years the research includes records of 557 cases, of which 178 (32\%) have led to violence and even death.

Some elements of the PNG experience are similar to that described for DRC in Africa. For example, the issue of interpersonal causal ontology whereby people ask not only why a misfortune occurred, but rather who is the malevolent person to blame for the trouble. This may sound far-fetched, but all too often (sometimes due to torture or fear of torture) the accused appear to enter into the sorcery narrative, leading to public confession of their guilt. There have been occasions where persons accused of witchcraft will argue over the body of a dead child, accusing one another of consuming vital

\footnotetext{
${ }^{1}$ Papua New Guinea (PNG), situated in the Western Pacific, above Australia, is home to some seven million people. The majority of the people live as self-employed farmers and agriculturists. PNG is culturally diverse with over 800 languages. Witchcraft and sorcery beliefs are common among many of the ethnic groups there.

${ }^{2}$ In the year 2000 census, $96 \%$ of the population identified as Christian. The Catholic Church is the largest Christian denomination with 27\%. Others major churches include Lutheran, United Church and Seventh Day Adventists. Pentecostal Churches were $4 \%$ of the population in the year 2000, but have grown rapidly since then (Gibbs 2004).
}

${ }^{3}$ The Enga Province is one of twenty-one provinces that make up the Independent State of Papua New Guinea. Sorcery and witchcraft is not part of Central Engan traditional culture. Such beliefs were found in areas bordering the province and they began to spread within the province only after 2010 .

${ }^{4}$ Background to the research is available at: http://www.stopsorceryviolence.org/improving-impact-of-interventions/. Research is funded by Pacific Women Shaping Pacific Development (Australian aid program). 
organs of the child, while at the same time saying that they themselves have disposed of part of the child's heart.

There are aspects of witchcraft belief in PNG that are different from that found in central Africa. In PNG, so far, few children are accused. Our study of over 500 cases has uncovered only two involving accusing a child under 11, and twenty one cases of accusations against young people between the ages of 11 and 18 years. In seven of these cases, the youth were the sole accused, while in the other cases, the young person was accused along with other family members and was not the primary suspect. Accusation of children under 11 years is rare in PNG, and that of youth is uncommon. Middle-aged persons between 41 and 60 years comprise over half of those accused. They are more likely to be male or female depending on the location in the country.

In the provinces we have studied in PNG, village leaders and family members are the most likely actors to make an attempt to resolve the accusation in a nonviolent way. Police have made an attempt in less than one in five cases. An attempt by a religious figure/pastor to resolve the accusation varies depending on the location. It is highest in the Enga province in the Highlands (47\%), and substantially lower in the island province of Bougainville (15\%) and around the capital city Port Moresby (8\%). Led by the Constitutional and Law Reform Commission, the various churches have produced a National Church Strategy to address sorcery accusation related violence. ${ }^{5}$ Catholic Bishops have taken a lead in condemning the violence and in questioning the reality of witchcraft, whilst Pentecostal and Revival churches often presume witchcraft/sorcery is real while offering support for deliverance from unwelcome spirits and evil forces. ${ }^{6}$

In PNG there has been debate about who are the victims of witchcraft. At first people identified the victims as those thought to be harmed by the witch or who face misfortune due to the malevolent actions of the witch. Gradually there has been an epistemological

${ }^{5}$ Sorcery violence faces holy war (2019).

Catholic Bishops Conference PNG/SI 2019.; Robbins, 2004.

${ }^{7}$ McCallum 2006.

${ }^{8}$ The Enga language translation of the New Testament does not include the term yama nenge. Simon the magician/sorcerer in Acts 8:9 is said to practice topoli mana-the practice of a ritual specialist. The magician Bar-Jona in Acts 13:16 is said to be a sambo potopesa-a false prophet. The term used for witchcraft in Gal 5:19 is a combination of timango minao and tomokaepi minaoliterally ghost-holder and poison-holder. The slave-girl said to have an evil spirit in Acts 16:16 is said to be a wanaku enjele koo paleta-literally a girl with a bad angel sleeping in her. The possessed man from the tombs in Mk $5: 2$ is also said to be akali enjele koo paleta-a man with a bad angel sleeping in him. One can see how the translators of the New Testament had to use borrowed terms like potopesa (prophet) and enjel (angel) to translate such concepts into Enga. In everyday life an increasing number of people are using borrowed terms such as sanguma or Satan.

Sil Bolkin 2018. 
have far less control. As noted by Priest et al. (41), the advent of Christianity has fostered new hybrid formulations, and sometimes the new "witchdemonology" acts as justification for utilizing deliverance methods on people understood to be the cause of other people's afflictions.

Consider the following example from a Lutheran pastor in the Enga Province.

When you look at this sanguma issue, the root cause is the evil spirit. The primary focus of Satan is trying to use people to accuse others. They are accusing others of taking the heart of a human person. When we go to the doctors, we find out that the heart is still there. There is no teeth mark or sign of sanguma eating a human heart. . . . The devil is falsely accusing the person. Then the person is tortured. That is all controlled by the devil and Satan is getting the glory. . . Because of our ancestors in the Garden of Eden lied to God, we were cursed by God. That is the root cause of all evil. Now the devil is playing that trick again and people start believing in it, and start accusing one another of sanguma and torturing innocent woman and girls. ${ }^{10}$

The pastor interprets sanguma (witchcraft) to be the work of an evil spirit identified as the devil, or Satan. While acknowledging the work of doctors he sees witchcraft accusations not simply as a person accusing another but rather from the big picture or viewpoint of the Genesis myth, of a universal tendency of people to be tricked by Satan. Such a viewpoint has implications way beyond the lustful feelings of yama.

Priest et al (40) refer to new hybridities as admixtures of meanings, categories, assumptions, actions and intentions. Healthy hybrid formulations result in contextualization, while flawed hybrid formulations result in syncretism. New hybridities emerge in PNG with reference to varying viewpoints or frameworks of ideas and beliefs through which one perceives and interprets reality. We call them worldviews. Our research identifies three principal worldviews: a magical worldview, a Christian worldview and a scientific worldview. Each of these worldviews gives rise to a different type of causal reasoning, emotions and ultimately behaviour. For example, in a situation where a person has died, the magical worldview is likely to support an interpersonal causal ontology in which a malevolent person (witch/sorcerer) is the proximate cause of the misfortune or death. A Christian worldview supports a faith-based causality in which God is the author of life and Satan is the opponent. The Christian prays with hope for a desired outcome, but life and death matters depend on whether one is allied with God or Satan as the ultimate cause. A scientific worldview promotes a rational view of the world with a scientific paradigm and laws of physical causality. ${ }^{11}$ Following a scientific worldview one will rely on the views of medical personnel or in the case of death, the findings of a post mortem.

These worldviews need not be held in isolation since the different causal reasoning systems can co-exist resulting in hybrid understandings where a person might hold all three worldviews at the same time. For example, a priest may offer a patient the sacrament of the sick with blessed oil (magical), commend the person in prayer to the will of God (Christian), and follow the physician's advice on what medication to take (scientific). He may even pray that the medication will be effective. In the case of sorcery accusations we have heard from nurses how they feel afraid of the tortured person accused of witchcraft lest they may in fact be a witch, yet they tend to the patient because he/she is a human person with the gift of life from God. At the same time they follow doctor's orders to dress the person's wounds. All three worldviews are at play in such cases and a simple bio-medical view would not be sufficient to fully understand the situation. Our research investigates how people decide to allow one worldview to dominate, and how and for what reason(s) one would change from a magical worldview that confirms the identity of a witch to one that could sustain alternative identities.

Christian priests and pastors in PNG are involved in awareness, defence and deliverance ministries, in response to witchcraft accusations. Amidst linguistic and epistemological shifts they are raising moral, ethical, and practical questions, while dealing with worldviews that rely on differing causalities. This is further complicated by theological trends promoting the demonization of the accused thus raising doubts about their identity and value as a human person. The challenge is to bring theological, scriptural, cultural and psychological insights into the debate in order to aim for an optimal solution.

\footnotetext{
${ }^{10}$ Interview by William Kipongi of Pastor Jeremiah, Wapenamanda, 25 March, 2019.

${ }^{\text {"I }}$ Subbotsky 2004.
} 


\section{References}

Catholic Bishops Conference PNG/SI. 2013 (29 July). Pastoral Letter on Sanguma-Catholic Bishops, Highlands Region, PNG.

https://www.voiceoftorot.com/news/png-highlandsbishops-wage-war-on-sorcerv-/ Accessed 1"January, 2020.

Gibbs, Philip. 2004. Growth, Decline, and Confusion: Church Affiliation in Papua New Guinea, Catalyst 34(2):164-184.

McCallum, P. Maurice. 2006. 'Sanguma'- Tracking Down a Word. Catalyst 36(2):183-207.

Priest, Robert J., Abel Ngolo and Timothy Stabell. 2020. Christian Pastors and Alleged Child Witches in Kinshasa, DRC. On Knowing Humanity Journal 4(1):1-51.

Robbins, Joel. 2004. Becoming Sinners: Christianity and Moral Torment in a Papua New Guinea Society. Studies in Subjectivity, 4. Berkeley: University of California Press.

Sil Bolkin, Kila Kapkora. 2018. Satan is Sanguma. But Western hegemony doesn't see it that way. http://asopa.typepad.com/asopa_people/2018/02/satan-issanguma-but-western-hegemony-doesnt-see-it-thatway.html. Accessed 1 January, 2020.

Sorcery violence faces holy war. 2019 (April 25). The National. https://www.thenational.com.pg/sorceryviolence-faces-holy-war/ Accessed 1 January, 2020.

Subbotsky, Eugene. 2004. Magical thinking and judgements of causation: Can anomalous phenomena affect ontological causal beliefs in children and adults? British Journal of Developmental Psychology 22:123-152.

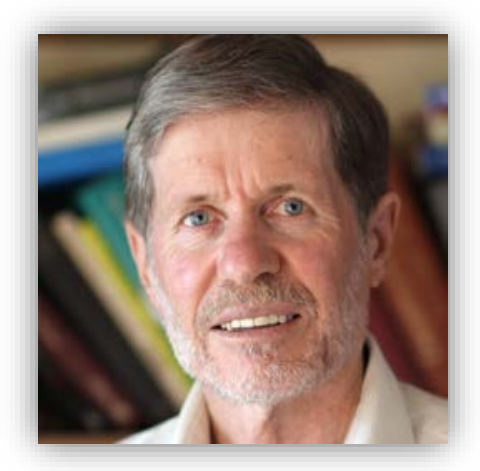

Philip Gibbs is a Catholic priest with the missionary Society of the Divine Word. He has been serving in Papua New Guinea since 1973. He has a Doctorate in Theology and a post-graduate Diploma in Anthropology. Currently he is Professor of Social Research and Deputy President of Divine Word University, Papua New Guinea.

Author email: gibbs199@gmail.com 